The Self in "Fieldwork": A Methodological Concern

Author(s): Beverly J. Stoeltje, Christie L. Fox, Stephen Olbrys

Source: The Journal of American Folklore, Vol. 112, No. 444 (Spring, 1999), pp. 158-182

Published by: American Folklore Society

Stable URL: http://www.jstor.org/stable/541947

Accessed: 07/10/2011 10:56

Your use of the JSTOR archive indicates your acceptance of the Terms \& Conditions of Use, available at http://www.jstor.org/page/info/about/policies/terms.jsp

JSTOR is a not-for-profit service that helps scholars, researchers, and students discover, use, and build upon a wide range of content in a trusted digital archive. We use information technology and tools to increase productivity and facilitate new forms of scholarship. For more information about JSTOR, please contact support@jstor.org. 


\section{The Self in "Fieldwork" A Methodological Concern}

As concepts of reflexivity and postcolonial perspectives have advanced our understandings of the way we represent those we study, they have also introduced a consciousness of the role of the self in research. This article reviews the history of the field of folklore with regard to the method of obtaining data or texts and demonstrates that collecting material contrasts with the practice of conducting research in the field. Pointing to a moment of transition, it shows that theories of folklore had to undergo significant change before methods of research would acknowledge the identity of the fieldworker and its significance.

ENTERING A CULTURE TO CARRY OUT ethnographic research, whether it is familiar or strange to the ethnographer, is much like looking into a pool of water. Depending on the light and the time of day, one may see a reflection of oneself, refracted perhaps because of the ripples on the surface. At sunset the reflection of the surrounding trees and foliage appear, and eventually one sees deeply into the water, simultaneously becoming aware of the underwater world, the forest, the sunlight, and one's own reflection. We find this analogy meaningful in our postcolonial world, in which all academic research has been problematized by issues such as history and catastrophe, boundaries and power, identity and reflexivity. Questions concerning authority, legitimacy, location, and intimacy, to name only a few, have rendered the static models of folklore and anthropology obsolete. ${ }^{1}$ In a recent article, George Marcus states, "Discontinuity in cultural formationstheir multiple and heterogeneous sites of production-has begun to force changes in the assumptions and notions that have constructed the traditional mise-enscène of fieldwork" (1997:96). Equally significant are developments in the academy. Michael Lambek has noted that it is "our 'discoveries' of feminism, race, transnationalism, displacement, and diaspora; the sheer growth in the number of practitioners, and the elaboration of a hierarchy of distinction among them-that

Beverly J. Stoeltje is Associate Professor of Folklore and Communication and Culture at Indiana University Christie L. Fox and Stephen Olbrys are Ph.D. students at the Folklore Institute at Indiana University 
have transformed fieldwork as much as any changes in 'the field' itself (profound as these have been)" (1997:35).

These changes have altered the topics of research, the theories that frame the enterprise, and the methods of fieldwork for folklorists and anthropologists alike. However, few features have proven to be more consequential than the identity of the researcher or, more specifically, the issue of the self. ${ }^{2}$ In her article on the politics of ethnography, Pat Caplan states this principle succinctly: "one of reflexivity's basic tenets, which is that of the self, including the cultural baggage which the ethnographer brings to the field, helps shape the ethnographic encounter" (1994:83). Lambek identifies this uniqueness of person as "historicity": "Every ethnographer brings his or her historicity to bear on the way he or she approaches the subject, conducts fieldwork, and resolves the interplay between the universal and the particular" (1997:35).

Although the topic of fieldwork has been the subject of numerous publications in the past decade, and increasing numbers of scholars go to "the field" from all disciplines, the actual negotiation and construction of self as a methodological concern in folkloric fieldwork remains a topic ripe for consideration. It is this topic that concerns us in this article and the two that accompany it. The authors reflected on their field research as they looked into the pool, metaphorically, and confronted, literally, the problems that arise when the expectations of the field are subverted by its realities. Olga Nájera-Ramírez journeyed to Jocotán, Mexico, to study La Fiesta de Los Tastoanes for her dissertation research and subsequent book (1997). In the article that follows this one she explores her identity as a Mexicana and as a Norteamericana, both of which informed her interactions with the residents of Jocotán. Shifra Epstein then recounts her fieldwork experiences with the Bobover Hasidic community in Brooklyn, New York, as she underwent ethnic reidentification. She examines her approaches to the study of a predominantly male Hasidic tradition and the negotiations necessary for her to move between the role of fieldworker and her identity as an Israeli-born secular Jew. Both folklorists interrogate the ideology underlying the notion of objectivity, take account of their identity as female, and, moreover, evaluate their position as insider/outsider; these variables are then considered in light of their implications for research.

With these articles we want to draw attention to the interactions of the self as a significant variable in the field and, simultaneously, to the gender of the self. Moreover, we want to emphasize the link between the larger endeavor of scholarly research and the processes of fieldwork, whether it be in a familiar or a strange environment, for it is fully apparent that practices in the field will reflect the scholarly paradigms and theoretical positions of the fieldworker's discipline at any given moment in time.

The processes of fieldwork are always imbued with questions of otherness. Who is the "other"- the persons who constitute the subjects of field research? A fieldworker may study her or his "own" people, those who are familiar; or, on the contrary, he or she may study individuals or a society who represent that which is strange or unknown. ${ }^{3}$ At one time many scholars believed in a dichotomy: folklorists studied their own people in domestic space while anthropologists went to 
foreign lands to research peoples strange to them. Today we recognize that the very activity of fieldwork places us somewhere on a continuum between familiar and strange, self and other, domestic and foreign, same and different. Wherever we are located on that continuum, however, certain practices inherent in the project of "people studying people" can be considered objectification. ${ }^{4}$

A new consciousness has brought to our attention issues of subjectivity and objectification, of gender and selfhood, and of the power of the state; and new methodologies are emerging in response. For example, in today's world it is essential for a fieldworker to understand the boundaries set up to protect the subject of research. No longer can one assume simple access to "the people" or "the folk society." University scholars and government officials in the nation-state or the local tribal council have authority to determine whether or not one may obtain a research permit. Moreover, even with such a permit, we now recognize that local gender practices will always place limitations on research. In addition, new copyright laws to protect intellectual as well as material property will soon affect how materials must be treated. These few examples and many more enter into the dynamics of any contemporary fieldwork.

Our goal with these articles is to focus attention on the dynamics of the self in the field. Reflecting on one's own identity and the relation of the self to the other heightens the awareness of the ethnographer and helps to bring into focus the relationship between the researcher and the researched. For example, I (Beverly Stoeltje) conducted fieldwork in my own culture (on rodeo in West Texas) for many years before shifting my research to Asante queen mothers in contemporary Ghana. Consequently, I conducted my first interviews among people who were familiar to me, recorded my first field notes on a subject known to me, and encountered my first difficulties where I spoke the native language and dialect and was expected to know the answers to my questions or to know better than to ask those questions. (West Texas cowboy culture was not familiar with the enterprise of fieldwork, and at times this posed a challenge.) Not only did this mean that I was more experienced when I carried out fieldwork in a culture other than my own, but it meant that members of that culture were not placed in the position of providing rites of passage for yet another dissertation student. This sequence of own culture/other culture had been a part of my plan from the time I began my graduate career, for I did not feel comfortable working in another culture until I had first looked at my own culture through the ethnographic lens.

When I did embark on my Ghanaian research, I found that individuals often asked me if I had studied my own culture, and when I answered that I had and could offer them reprints, they seemed considerably more receptive to my research. Equally relevant, because I was familiar with the importance of kinship, having listened to Texas families explain who was kin to whom and who married whom, I did not find the Akan concern with kinship to be so exotic, though certainly it was a different system. Neither did I find concepts of hospitality, reciprocity, or the rhetoric and strategies of political activity strange. That is not to say that I would deny social and cultural differences or that the system known as chieftaincy was not difficult to understand as it is actually performed but, rather, 
that fieldwork in one's own culture familiarizes the researcher with many institutions and social processes present in other societies as well. This familiarity reduces some of the strangeness felt by the researcher when studying a people different from the self, allowing her or him to recognize conventionalized social behaviors more readily. Researchers who have worked first within their own demographic group, then, are less likely to have difficulties seeing similarities between their own and other cultures. By looking at one's home culture through the lens of fieldwork, one has in a sense objectified the self and is less apt to objectify the "other" with the techniques of the ethnographic exotic, oblivious to social processes that characterize one's own culture.

These issues point to questions of cultural relativism that have long focused on cultural differences in an effort to create understanding of peoples different from each other. We present these articles from the perspective that human relationships are best described like a kaleidoscope in which certain types of lived experiences are shared by human beings but may be organized differently, while others contrast significantly, causing us to create communicative forms incomprehensible from one culture to another. Folklorists and anthropologists have taken the lead in research that expands our knowledge of those different from ourselves by some measure, and many continue to focus on modes of communication within and across social groups. Added to these concerns, however, is the role of the self in the research. A fieldworker who understands the self and the dynamics of the relationship between self and other in the field, regardless of whether one studies with a culture that is familiar or strange, will reap the benefits in the quality of the research. ${ }^{5}$ In these essays, then, our goal is to locate, give recognition to, and examine those experiences in which the fieldworker negotiates, constructs, and performs the self, thereby contributing to the growing consciousness of the self as a methodological concern.

\section{Early Ethnographers}

Although these issues have been widely articulated only in the past two decades, we recognize that they were explored or acknowledged by individual scholars who preceded us and who either challenged existing practices or contributed to a conceptual consciousness of the research relationship long before we developed the language to address the subject. Two individuals in particular deserve mention in this regard, Elsie Clews Parsons (1874-1941) and Zora Neale Hurston (1891-1960). Although neither of them used the terminology we use today, both pursued research topics that represented an extension of their identity and intellectual interests and that applied the expertise of the self to define and shape their research.

Parsons transformed her interests in feminist sociology and her own experience of motherhood (she gave birth to six children, four of whom lived to adulthood) into the study of the Pueblo construction of gender, focusing especially on women and reproduction. ${ }^{6}$ As Barbara Babcock (1991) explains in her introduction to the collection of Parsons's essays published as Pueblo Mothers and Children, Parsons did not regard maternity and feminism as incompatible. Consequently 
she developed close relationships to Pueblo women and published articles on reproductive practices and beliefs which recognized not only increase as the ideological focus of Pueblo life but also "that continuity over time is a political and symbolic as well as a biological matter" (Babcock 1991:7).

Parsons was aware of and drew attention to the influence of the anthropologist on the narration of tales when she noted that the narrators who knew her particular interests would include details for her in their tales. Babcock quotes her as stating, "Wedding minutiae would get into almost every tale of the First Mesa narrator who knew I was interested in Hopi weddings" (1991:8). Parsons's observation concerning the narrator's adaptation to the audience was not widely noted at the time, but decades later students of narrative would rediscover this and hail it as a great breakthrough in the study of narration. Acknowledging the connection of the ethnographer's identity to the data, Babcock argues that Parsons's gender and politics shaped both the substance and the style of her work, "influencing what she studied, whom she talked to and how she wrote about it in both published and unpublished contexts" (1991:4).

Zora Neale Hurston was a fieldworker, scholar, and writer whose work also embodied her gender, life experience, and intellectual orientation, all of which presented a challenge to scholarly conventions of the time. Decades before scholars who were members of ethnic-minority groups would conduct research in their own communities, and long before folklorists would introduce theories of performance into the field, Hurston returned to her own African American community to conduct ethnographic research. She traveled from Columbia University, where she studied anthropology with Franz Boas, back home to Eatonville, Florida, where she documented folklore as it was performed in everyday life. She then continued across the South to New Orleans, where she studied voodoo, and later worked in Haiti and Jamaica. She published her research on African Americans in the South as Mules and Men in 1935 (see 1990). In it she defied scholarly conventions of the time and presented the tales, games, beliefs, music, rituals, and customs as they were performed by specific characters whom she brought to life in social settings. She emphasized the context of the folkloric event by representing the circumstances of the performance, right down to the "terrified chickens flop[ping] and flutter[ing] frantically in the dim firelight" in a voodoo ritual (Hurston 1990:204). Her narrative style, however, read more like fiction and did not follow the standards for folklore publication at the time, which called for full transcription of the text but did not require information about the speaker or the setting.

Hurston's work was innovative, creative, and challenging, but in the context of our discussion of fieldwork, we want to emphasize her relationship to her research community. She was African American and returned to her own people, in her own region of the country, to document folklore as it was performed in social life. Prior to this time, most collectors of African American folklore were outsiders to the community, usually in ethnicity and class. Certainly, she was the first African American to receive graduate training and return to her own community in the South to do ethnographic research. Although folklorists generally worked 
in their own country, they collected folklore primarily from social groups different from themselves (this group of folklorists included Elsie Clews Parsons).

Hurston's entire project represented a major innovation, but of special interest to us is her exploration of the relationship between the self and the subject of her study. Throughout Mules and Men she reports her own personal experienceswhat she said and what happened to her as she pursued folklore and its place in the lives of the residents of Eatonville. She used the same methodology in New Orleans, where she apprenticed herself to several voodoo practitioners. The experiences she chose to pursue as a participant required a demotion of the self from the privileged status she could have enjoyed as a consequence of her education, but they also gave her access to the intimate knowledge of ritual, belief, and social relations, all of which she reported in rich detail.

Nevertheless, when Hurston published her work her contemporaries gave it mixed praise and often rejected it. In his recent dissertation, Edward Pavlic (1997) provides a full discussion of her contribution, describing her literary work with the term diasporic modernism, and reviews the critics' response to it. ${ }^{7}$ The African American intellectual community, often described as the Harlem Renaissance, viewed her work as a representation of African American life they hoped to change forever, erasing any record of its existence. Whites gave it mixed reviews, depending largely on their political perspectives. Pavlic states that Hurston was no stranger to the absurdities expressed by her reviewers, but overt responses to these criticisms was never "a prominent facet of her creative process" (1997:154-155). He contrasts her work with Ellison's: “where Ellison generated an 'immersion' sense of connection to the American South tinged with cultural universalism, Hurston developed theory emphasizing the African presence beneath the American South" (1997:157-158).

Hurston attempted to emphasize the role of language in the community, reproducing the spoken text in dialect and displaying the artistic features that characterize the performance of folklore and give it meaning in social interaction. This was one of the features that elicited reproach. Folklorists and anthropologists would theorize the importance of speaking in African American culture later in the 20th century, but at the time she wrote few could appreciate her contribution. Hurston challenged the prevailing conventions of both folklore and anthropology by her presentation of the texts situated in social situations. Because she did not engage in scholarly discussion about her methodology, explaining her goals and purposes, scholars and writers alike criticized her. She has since been enthusiastically reclaimed by African American writers, but folklorists and anthropologists have remained ambivalent about or unaware of her work. ${ }^{7}$

\section{Folklore Models and "the Other"}

Hurston was working against a model that isolated texts from those who used them in the course of social life. This model was acknowledged in 1942 by A. H. Gayton in an essay published by the Journal of American Folklore (JAF). She explained that both anthropologists and folklorists work with tales, songs, dance, 
and beliefs but that while anthropologists concern themselves with the whole culture of which the arts are a part, folklorists are confined to the arts alone (Gayton 1942:123). When the field did begin to expand, quite different issues occupied the center of the debate. Under the influence of Richard Dorson, the major problem deserving scholarly attention was the need to distinguish the study of U.S. folklore from European folklore and to introduce a new method of research that rested on a historical model. Dorson argued that the U.S. folklorist was faced with the need to "fashion his own platform and define his own targets" (1959:209). Reflecting his background in U.S. civilization at Harvard, Dorson argued that folklore research in the United States should follow a model that acknowledged the "great dramatic movements of American history" and attended to the diversity of the population and its experience (1959:203). Published as "A Theory for American Folklore" in 1959 in the $J A F$, his essay outlined the conditions unique to the United States (such as colonization, the westward movement, immigration, aborigines and slaves, regionalism, patriotism and democracy, mass culture) and urged folklorists to locate their research in these domains. ${ }^{8}$

The erudite nature of the article displays Dorson's command of the diversity and complexity of "American civilization" as he chose to label it, but the question of methodology hardly rates attention at all. Speaking from the paradigm of the omnipotent researcher, he describes folk culture as a "target": "The regional folkculture complex offers the American folklorist one of his most inviting targets" (1959:209). Although he was arguing for a new theory of folklore based on U.S. society, he nevertheless relies on archaic concepts of folklore, which he located in the shadows: "such regions and pockets stand in contrast to the general American mass culture or urbanization, industrialization, and other-direction. The folklorist is particularly qualified to investigate these shadowy corners of American life" (1959:210).

Ironically, in the same issue of $J A F$ we hear the voice of an individual from one of those regional "shadowy corners." Arkansan Eugene Haun presents the "insider" perspective on "outsiders" who come to the South in search of folklore. He describes the influx of northerners into the state during World War II and comments on their fascination with Arkansas folksongs and folkways, in spite of their complete lack of understanding. These "intruders" were not scholars, but in their enthusiasm for "the folk" they displayed traits frequently seen in the zealous folklorist who approaches "the field" with no reflexive capacities. Representing the view of those being "targeted" as folk, Haun has a sharp eye for the encounter between self and other. He describes the "other" in search of Arkansas folksongs in the following:

Quite deliberately they would put on what the mountain people knew to be work clothes, and quite deliberately they would avoid shaving, thereby creating an initial atmosphere of distrust, for the people in the country knew that they were city people, anyhow. Furthermore, they knew that city people who were up to any good always shaved and always wore clothes fine enough to be laid out in. Then the intruders would try to get the locals to tell them where there was a singin' woman. The country people would be at first suspicious, then incredulous, then amused to think that anyone 
would come amongst them, over their implausible roads, in such an outlandish rig, to hear Mix' Quackenbush sing, when it was all they could do to get the old woman to shut up. [1959:243]

On the subject of "folksongs" and "folkways," he explains,

We didn't sing folksongs. We thought they were tacky. They were part and parcel of the backbreaking farm labor, the dirt, the poverty, the violence, the superstition, the fear-ridden religion, and the listless ignorance of the Reconstruction period which we had come to town to escape. [1959:243]

We didn't lose our folkways: we abandoned them; we tossed them over; we pulled ourselves up out of them as rapidly and as far as we possibly could, with long sighs of relief and loud cries of joy. [1959:244]

Haun also includes his own particular experience with the "outsiders," describing his reaction as a feeling of being "tainted": "In spite of all my care, I found that one turn of my phrase or another would make my new acquaintances ecstatic as they recognized the 'true folk tinge,' as one of them called it, a turn of phrase which made me feel somewhat tainted. But I kept my songs to myself' (1959:244). Yet his feelings did not inhibit his ability to make the following insightful observations: "How astonishing and pathetic then to observe the strivings of persons who yearned for these hobbles and stays! For that's what it was, a yearning-to return to sources from which some of them had not flowed in the first place, to be something which they could not become, to possess something which could only be bequeathed from father to son, and that not wittingly" (1959:245).

We have quoted extensively from Haun's essay because he articulates with such passion and with such incisive accuracy a perspective of those "targeted," one that is rarely seen on the pages of academe. In so doing, he addresses some of the key issues that define the relationship between the folk and the "elite" who come to collect from them, most importantly the folklorist who wants to locate the folklore and become the voice of the folk but who insists on ignoring the povertystricken conditions in which the folk are all too often forced to live.

We should point out that Dorson was editor of $J A F$ at this time. We may assume, then, that Dorson did not perceive Haun's "intruders" as examples of his proposed cadre of U.S. folklore scholars but, rather, as one of the "seven leading types" of variegated folklorists he considered to be "inapplicable" to the study of folk traditions in the United States. One of the seven categories is "folksong and folkmusic specialists." 9 (The others are comparative folklorists, cultural anthropologists, special pleaders, regional collectors, literary historians, and popularizers.)

The question of reflexivity and the fieldworker also appeared in Claude LéviStrauss's Tristes Tropiques (1955), in which he drew attention to the effects of fieldwork on the fieldworker. He argued that fieldworkers often go abroad to find something in themselves, and in creating the distance between one's own culture and oneself, the anthropologist could better understand her or his own culture. His other works, too, contain similar insights buried in the larger texts. In his introduction to The Raw and the Cooked, Lévi-Strauss describes himself as proceeding 
in the manner of Kantian philosophy, but the ethnologist, unlike the philosopher, "does not feel obliged to take the conditions in which his own thought operates, or the science peculiar to his society and his period, as a fundamental subject of reflection in order to extend these local findings into a form of understanding, the universality of which can never be more than hypothetical and potential" (1969:10-11).

In these views on fieldwork and on the act of reflection Lévi-Strauss prefigured the introduction of reflexivity into ethnographic theory, or perhaps introduced it himself. Ironically, it was also the subject of reflection on one's own cultural assumptions that led to the critical evaluation of models based on binary oppositions, one of the foundational elements in Lévi-Strauss's structuralism. As this theory ceased to dominate the study of culture, new issues emerged in the later 20 th century such as those concerned with authority, gender, class, colonialism, power, and difference, to list a few. The paradigm of the omnipotent researcher, whereby scholarly works were written and received without attention to the researcher's identity, perspective, or worldview, has since given way to models that take account of the role of the researcher. With increasing thought and philosophical argument dedicated to identity politics today, we have become aware that all aspects of the researcher's identity are relevant to the fieldwork enterprise. Such matters as whether one is female or male, a student or professor, married or single, a native or stranger, has children or not, and many more will affect the relationship between the researcher and the researched and, consequently, the results of the study.

\section{The Transitional Decade: From Collecting to Research}

Within the field of folklore specifically, these issues concerning fieldwork could not be introduced into the scholarly debate until the early models for the study of folklore had been scrutinized and new theories generated. ${ }^{10}$ Because the term folklore served as an index of preliterate societies from the time it was introduced by Thoms in 1846, and long before that as the oral poetry and narratives of the Volk, it was thought to represent a phenomenon that was fast disappearing. Therefore, the goal of those interested in this fast-disappearing body of "oral tradition" became the collection of the texts representing this stage of human development and era of history. Spurred on by nationalism, colonialism, and the spread of literacy, the idea of collecting folklore spread around the world. Unlike so many other academic endeavors, however, the scholarly pursuit of folklore never fully separated itself from those individuals who engaged in the collection of folklore as their leisure activity, motivated by a romantic longing for an idealized past, by political sympathies, or, in some cases, by the belief that these practices and customs should be erased in order to clear the way for progress and enlightenment. For both the "collectors" and the scholars the goal remained the text itself.

Questions concerning the meaning of the text or the methods of collecting it were not asked until the mid-20th century. Recognizable many years later as the debates over text and context, the effort to shift the folklorists' attention to context 
as well as text brought dramatic changes to the study of folklore. The effects of these changes on folklore fieldwork have been described by Ruth Finnegan (1992) as a change of the role of the researcher from collector to participant-observer. In the past, she argues, fieldworkers entered a community in order to "extract" data, whether that be stories, kinship relationships, or puberty rituals. Now folklorists tend to assume a participant-observer stance within a community, identifying the context in which folklore genres are actually performed, used, created, or adapted. Opening the door to major change, this shift moved the study of folklore away from the collection of disembodied texts to an emphasis on the enactment, creation, use, or performance of folklore by specific individuals in variable settings.

This paradigm shift took place in the 1970s, a decade that qualifies as a transition period. In order to trace this comprehensive and, at times, controversial shift, we want to focus on selected works that serve as guides, marking the significant points in the transition. A watershed year for the field of folklore, 1972 saw the publication of Folklore and Folklife (edited by Dorson), African Folklore (also edited by Dorson), and Toward New Perspectives in Folklore (edited by Américo Paredes and Richard Bauman): three important volumes that charted the terrain of the past and future of folklore. In the introduction to the first of these, Dorson surveyed the history and theory of folklore and acknowledged a new group of scholars who rejected "the older static typology of folklore texts" and stressed a "three-dimensional context" (1972b:45). He noted that in this new model of research "fieldwork will become a more elaborate enterprise than the securing of verbatim texts" (1972b:47). It was, however, in his introduction to African Folklore that he stated his most fundamental ideas on folklore and fieldwork with a wealth of pronouncements on the subject. ${ }^{11} \mathrm{He}$ argued that the study of folklore (as an essentially Western phenomenon) required "a chasm between the learned and the tradition-oriented classes" (1972a:3). Folklore research in Africa was becoming possible, it followed, because an intellectual class had begun to emerge and with it a distinction between elite and tribal behavior. Like the folklorists and antiquarians of the past, Dorson believed that the enterprise of folklore could only be undertaken when modernization was established and a group of elites was trained that could collect the folklore from those left in the shadows. He shared another view with his ancestors also, and this one separated the fields of folklore and anthropology, designating only the fragments for folklore:

Ordinarily the folklorist considers magic, witchcraft, sorcery, and demonology as his prime topics because they lie in the shadows of the high civilization proud of its science, engineering, education, and theology. But when they infuse the central institutions of a tribal culture, they are better studied by the anthropologist. The methods of the folklorist are directed towards the esoteric, the fragmented, the little-observed parts of the culture. [1972a:31]

These two positions were consistent with the old mode of folklorist as collector of esoteric, no longer relevant texts. In this view the definition of the folk and thus their folklore depended on an evolutionary model of society and on a particular moment in that evolution. These parameters for the study of folklore did not even 
acknowledge the paradigm based on genre, the concept of the arts, or the function it served but, rather, remained imprisoned in the notion of fragments to be found in the shadows. The folklorist, as investigator into the more "shadowy aspects" of nonelite culture, was allowed the special status of collector of fragments. This view of fieldwork presumes a self separate from and much higher than that of "the other" on an extremely refined axis of relationship. It simultaneously defines that relationship as marginal to mainstream society.

Although Dorson acknowledged the "Young Turks" of folklore and their influence on the field, his view of folklore and fieldwork remained inconsistent with the growing emphasis on participant-observation of performances, new definitions of "the folk," and, in our view, even with his own call for research based on his new theory of U.S. folklore. Over time, an emphasis on context and performance wrested the researcher from this artificially privileged position as collector of archaic, antiquated texts. It erased the notion that folklore was restricted to marginal groups or minorities, and abolished the idea that an elite class was required to collect those fragments from the past.

The new theories responsible for these changes were articulated in Toward New Perspectives in Folklore, published first as a special issue of the Journal of American Folklore in 1971 and then as a book in 1972. The marked difference in orientation was apparent in the titles of the essays: "Personal Power and Social Restraint in the Definition of Folklore," "Differential Identity and the Social Base of Folklore," and others that introduced new viewpoints. The editors, Paredes and Bauman (both teaching in the Folklore Program at the University of Texas), clarified their purpose in their opening statements. Paredes noted that meaningful dialogue had been scarce in the discipline because folklorists (like some social scientists) had looked on theory less as the basis for sound methodology and more as pronouncements with emotional, if not moral, implication (Paredes and Bauman 1972:iv). Bauman stated that the authors represented "a new generation of folklorists who were not content to remain within the confines of inherited intellectual pigeonholes" (Paredes and Bauman 1972:ix). A wide range of issues affecting the field were addressed, but among the most significant was the image of pastoralism, taken up by Roger Abrahams. That the idealized peasant community has been an important image in the intellectual milieu from which folklore emerged has been well known, he argued, but the motive for going to the peasantry for anything at all is suspect in the Western intellectual enterprise because the "pastoral" image is constituted of the city person's imagination-how he or she imagines the countryman or the "savage" to live (Abrahams 1971:20). As Abrahams also states, "Pastoralism is a conception of country life with most of the rudeness, roughness, and lack of comfort and most of the smells, tastes, and feelings subtracted from the accounts" (1971:21). In this analysis of the pastoral we find the explanation for the collectors in Haun's essay who put on overalls and went in search of folksongs in Arkansas, as well as many others who collected in the "countryside" and represented and interpreted "the folk" for the city.

Although these concepts were profoundly influential on the rising generations of folklorists, change was not accomplished with only three publications, nor was 
it all to take place in 1972. Equally as significant at this time was the publication of a special issue of the Journal of American Folklore entitled "Women and Folklore," which was republished as a book (Farrer 1975). The first book on the subject of women and folklore, it was edited by Claire Farrer and includes eight essays in addition to the very useful introduction surveying folklore scholarship pertaining to women. Without addressing the matter of fieldwork specifically, all of the articles reflect in-depth fieldwork and interpret the concept of folklore more broadly than the collection of texts. In each of the essays, questions of identity and the relationship between researcher and the researched are not far below the surface.

The majority of the articles present data drawn from fieldwork, but even those that utilize literary sources rather than data collected in the field are based on fieldwork conducted in the culture that produced the literary texts. When Abrahams published his article on representations of Black women, he had already conducted years of research in African American and Caribbean cultures, and I (Stoeltje) had begun to carry out folklore research in my "own" culture, collecting stories from my father, one of which stimulated me to write the article in the collection. ${ }^{12}$ In the end, I found that I so disliked my father's story about my mother's challenge to his authority that I chose to exclude all fieldwork narratives from the article. Instead I created a model of images from diaries and published narratives that I knew to reflect contemporary gender relations as well as those of the frontier (Stoeltje 1975). However, I did not mention my fieldwork or my life history as the basis for the article. At that point in time, it was acceptable to conduct fieldwork in one's own community and even in one's own family, but it was not yet conventional to acknowledge these relationships in print. When I included verses about women from a cowboy journal of the 1880 s, I included the cowboy's name (J. W. Kennedy) but not the fact that he was my grandfather.

Just as I have excavated from my essay some significant details that relate my identity and my fieldwork to the published article, each of the other authors could do the same, revealing a connection between the self and the subject, valuable because it shapes the outcome of the process. While this collection was pathbreaking as the first publication devoted to the subject of women and folklore, and suggests throughout its pages the relationship between the self of the author and the subject of the article, it also reflects the difficulties associated with these questions. Despite the fact that all but one of the articles are authored by women and the subjects center on women, discussion of the issues relating to identity and methodology is barely evident.

In contrast, identity and methodology specifically constituted the subject of a 1977 article by Américo Paredes (see 1993). The article, entitled "On Ethnographic Work among Minority Groups: A Folklorist's Perspective," addresses the problems raised by Anglo anthropologists who have chosen Mexican American culture as their research topic. With the critical eye of a scholar from inside the culture, Paredes identifies the many instances in which the outsider/ethnographer explains data incorrectly because he or she (1) imposes stereotypes held by the dominant culture, (2) is unfamiliar with the use of folklore performed to comment on social and political situations, and (3) does not realize the multiple ways 
that language can communicate meaning. Paredes discusses specific performance strategies such as double imitation (based on the esoteric/exoteric factor), several kinds of role attribution, mock memorates, reported practical jokes, parodies, and the frequent manipulation of stereotypes in these performances. Throughout the article he directs attention to the failure of the ethnographers to distinguish between factual reports and the performance of folklore, which often allows for the “operation of stereotypes" (1993:107). Making a plea for all ethnographers to be aware of the informant as a potential performer of folklore, Paredes emphasizes that "the Anglo ethnographer may be too quick to accept as genuine the informant's persona that most nearly corresponds with the ethnographer's own unstated, consciously rejected prejudices" (1993:110).

With regard to the study of folklore, then, the decade of the seventies serves as a transitional period. Folklore research shifted from collecting texts to investigating the performance, meaning, and uses of a wide range of folklore forms and related acts. Rather than searching for fragments of the antiquated past, folklorists began to engage in participant-observation and to recognize that the relationship between the folklorist ethnographer and the subject of study involved a serious consideration of identity and the power relations invoked by the research relationship.

\section{The Early 1980s: A New Consciousness in Fieldwork}

The first fruits of these efforts to transform the field of folklore began to appear in the early 1980s. A brief look at selected publications of these years reveals the influence of the new methods and paradigms. Illustrating the new approach to fieldwork based on context, performance, and interaction as developed at the University of Texas, the 1981 festschrift for Américo Paredes was entitled "And Other Neighborly Names": Social Process and Cultural Image in Texas Folklore. Edited by Bauman and Abrahams, younger colleagues of Paredes, and authored by his students and associates at the University of Texas, the collection of essays features research on particular forms of folklore in the various cultures of Texas (panaderos [bread makers], "lying," curanderos [folk healers], rodeo, corridos, and others). These folklorists incorporated rich data from extensive fieldwork in the differing regions of Texas, including the "border," so important to Texas/Mexican culture and to Paredes's own research. Representing the very different experiences of the several cultures that occupy the space known as Texas, the essays consider cultural conflict, social change, and differential identities while dealing with the interrelation of belief, stereotypes, image, and text within the context of performance.

Yet another style of folklore publication appeared in 1982 when Marta Weigle published a resource book on women and myth, Spiders and Spinsters: Women and Mythology. Although the work reproduces Greek and Native American texts of myths that feature women alongside published commentaries on those texts, the concluding chapter discusses scholarship on gender in contemporary societies and calls for fieldwork based on social interaction that will advance our knowledge of the relationship between myth and gender in current social life. In the following year, another significant publication appeared, directly concerned with methodologies. 
In the Handbook of American Folklore (1983), Richard Dorson devoted himself to the development of a broad statement on folklore research. A voluminous work, this collection attempts to provide a comprehensive guide for research in U.S. folklore and therefore includes articles that focus on specific genres or categories of folklore, ethnic groups, methodological matters, and theoretical issues as they implicate fieldwork. The broad vision of this collection reflects Dorson's effort to incorporate both the innovations of the past decade and the conventional approaches of previous eras. What is of significance to our present concerns, however, is that the majority of the essays are devoted to the processes of research carried out in the field.

Two decades later we can say that the published scholarship discussed above not only marked a transition, and indeed shaped the era to come, but definitively altered the concept of fieldwork from a collecting task to a project of serious research, opening the way for the role of the researcher to emerge as a topic for consideration. In our search for the self in the ethnography, we want to turn now to a more primary source of data, less entrenched perhaps than the published works just mentioned. Recognizing that the Ph.D. dissertation is a site where new paradigms are often tested out and innovations introduced, we looked briefly at those accepted at Indiana University's Folklore Institute during this period to determine if and how these conceptual frameworks were reflected in the new writings of folklorists. This notion sprung from an effort to catalog and categorize the dissertations held at the institute in order to make them more available to the students and faculty, with the notion that knowledge of this large body of work would educate us about the field itself. ${ }^{13}$ Only those dissertations that exhibit some consciousness of the role of researcher, consider the subject from new perspectives, or indicate an awareness of the self will be mentioned in this brief discussion, however. A few dissertations, selected from the same period (the early 1980s) and using the same criteria, completed at the University of Texas will also be mentioned. We recognize that an essay comparing the dissertations accepted at the various graduate institutions around the country during this transition period and in the decades since would be a valuable statement, informing us of the general patterns of folklore research in the later 20 th century. Unfortunately, that survey lies outside the purview of our present effort and must await a future article.

An early mention of researcher consciousness was made by Robert J. Smith in his 1969 dissertation on a Peruvian patronal fiesta (in Otuzco) in which he acknowledges that his capacity as a researcher changed "given the nature of the fiesta, the more I participated, the less I observed" (1969:3) ${ }^{14}$ Issues concerning the constructed identity of the informant gained popularity in the 1970 s, with a rash of students exploring themes outside the boundaries of "text." Robert Jesse Adams (1972) serves as a good example of this broadening; he wrote his dissertation on one Japanese storyteller and included an analysis of the relationship between the teller, the tales, and the community. By 1975-76, some Indiana dissertations had begun to reflect the influence of feminist thinking, particularly those written by women using nontraditional methodologies. Rosan A. Jordan (1975) and Sandra Dolby Stahl (1975) both addressed the relationship between the researcher and 
the informant in some detail, examining how their personal relationships with friends or family respectively influenced the context, amount, and type of data collected. The discussion of identity (of the informant and the researcher) grew steadily in dissertations throughout the early 1980s. ${ }^{15}$ Two examples of this growing direction in fieldwork are Dorothy S. Lee's 1984 "Music Performance and the Negotiation of Identity in Eastern Viti Levu, Fiji” and Roberta L. Singer's 1982 "My Music Is Who I Am and What I Do: Latin Popular Music and Identity in New York City." Singer, in particular, tackled urbanites, Latino Americans, and popular music in a dissertation that helped push the boundaries at Indiana.

At the University of Texas dissertations in the early eighties also began to address concepts of identity and to display an awareness of the self. Significant in this regard is Edward K. Miller's dissertation on women singers in Scotland, "An Ethnography of Singing: The Use and Meaning of Song in Three Generations of a Scottish Family" (1981). Miller took into account the relationship among singer Janet Weatherston, her mother, and grandmother (also singers) and how the context of their singing changed with the folksong revival, shifting from the domestic space to the stage of the folk festival. With regard to his own identity, he explained that his research was facilitated by the privileged relationship he enjoyed because of his own role as a Scottish singer who performed in many of the same folksong festivals as Weatherston. In 1983 Marilyn White completed a dissertation on her family and ancestors in Virginia, " 'We Lived on an Island': An AfroAmerican Family and Community in Rural Virginia, 1865-1940.” Representing a shift from the paradigm in which white researchers collected African American folklore, she studied her own African American family and the dynamics of their relations with the whites in the same region, a project an "outsider" would be unlikely to undertake.

Equally relevant, in her dissertation "Quilting and the Pattern of Relationships in Community Life" (1984), Joyce Ice dealt with a group of quilters in the small town of Lytton Springs, Texas, and approached their activity as a framework for viewing their social life as well as an expressive form involving both material objects and people. Of particular interest, she documented their community role as organizers and fund-raisers for the annual homecoming event and gave special attention to her own role in the group (she learned to quilt and became a full participant in the quilting sessions). Drawing on her own experience, Robbie Davis Floyd completed her dissertation on childbirth, "Birth as an American Rite of Passage" (1986), after giving birth to two children. From an initial project in which she collected women's birth narratives she built a model of childbirth as ritual, utilizing her data to interpret the effects of technology and the role of the medical establishment on the birth experience. Throughout her work she employed perspectives from her own experiences and the subjective responses of other mothers as well as research from medical science. Finally, one more dissertation deserves mention in this context. Our topic was addressed directly at yet another location by folklorist Margaret R. Yocom. Her dissertation, completed at the University of Massachusetts in the English Department, concerns personal relationships and fieldwork practices. Entitled "Fieldwork in Family and Oral History: A 
Study in Methodology" (1980), the work dedicates sections to the study of researcher bias, motivation, and self-exploration, recognizing the range of problems involved with identities when conducting fieldwork in one's own family.

While this commentary on Ph.D. research in the early 1980s is all too brief and represents only selected examples from two of the Ph.D. programs in the country, we believe it nevertheless points to the fact that the researcher was wrested, for the most part, from the artificially privileged position occupied in the past and from the notion that folklore existed only in fragments, located in shadows. The dominant paradigm stating that folklore research necessitated an elite class to collect text fragments from marginalized people was abolished.

Much of this reorientation was stimulated by the advent of feminism, both in the ethnographic sciences and in the larger social movement that developed in the 1960s and 1970s. Consequently, the number of women who entered graduate school increased, and some (in folklore) were explicitly interested in questions raised by the feminist movement. Not only did this avenue of thought call into question the phenomenon of "objective" research, it challenged the very ethical structure of it, especially the practice of "studying down," that is, conducting research only on groups of lesser status than the ethnographer (such as those considered "the folk"). Perhaps even more influential was women's experience. As increasing numbers of women went to graduate school and then into the field, and as they compared notes from an informed point of view, they discovered the fallacies of "objectivity" and the many other devices constructed exclusively for males. Consequently, whether or not a woman had chosen to study women, and whether or not she considered herself a feminist, most women eventually came to recognize that their identity as women would affect their research and their relationships in the field as well as in the university. This recognition led to the publication of a rich body of work concerning the influence of gender and identity in the field, but we are still in the process of exploring the significance of these factors for research (see Abu-Lughod 1990; Golde 1970; Hollis et al. 1993; Jordan and Kalĉik 1985; Whitehead and Conaway 1986; Wolf 1996).

Although we lack the space to review them all, two specific studies are deserving of mention here because of their specific focus on the self and the relationship of the self to the research subject. In 1986 Tony Whitehead and Mary Ellen Conaway published Self, Sex and Gender in Cross-Cultural Fieldwork, an exploration of the role of the identity of the ethnographer. Conaway confronts the illusion of objectivity head-on in her description of fieldwork in Venezuela. She asserts that "we've all pretended that the influences of our sex and our gender can be substituted for by talking to the right informant" (Whitehead and Conaway 1986:52). She objects to the notion of objectivity and its presentation as a "viable option" today, concluding that gender neutralization "is not a possible, nor even a necessary or desirable, mode for field research" because "more than theoretical or ethical neutrality is [now] possible" (Whitehead and Conaway 1986:61).

Ten years after Whitehead and Conaway, Diane L. Wolf edited a collection of articles that directly confronts the fieldworker's basic lack of sufficient tools to deal with a changing definition of self in the field. This volume centers on the researcher's 
definition and understanding of self in her or his home culture so that the inevitable challenge of these definitions can be understood and negotiated in relation to the research. The book's articles almost invariably contain anecdotes describing the author's realization that her or his relationship with informants affected the data. The relative novelty of this publication demonstrates that ethnographers are still coming to terms with these relationships and the impact they have on their work.

More recently, with the rise of feminism, contextualism, and the increasing trend of self-perception within research, fieldworkers have begun to seek solutions to the problems presented by a recognition of gender roles and intracultural dilemmas. Fieldworkers discussing the issues raised by objectification of the researched found that many principles of fieldwork were integrally linked to colonialism, power, and gender and therefore could no longer be assumed. Lila Abu-Lughod (1990) has reviewed this critique in her exploration of the question "Can there be a feminist ethnography?" She concludes by acknowledging the rise of indigenous anthropologists and "halfies" (people between cultures) and argues that

both feminist and halfie ethnography are practices that could shake up the paradigm of anthropology itself by showing us that we are always part of what we study and we always stand in definite relations to it. .. Feminist ethnographies ... can also make clear our relationships, since it is a pretense to think that we do not live in one interconnected world. [1990:27]

\section{The Reversal of the Relationship}

An effective exercise that brings many of these principles into view is the reversal of fieldwork relationships. Reversing assumed relationships in ethnographic research makes visible and even exaggerates some issues that may be impossible to imagine otherwise. The issues we refer to include the processes of representing the other, of interpreting the unfamiliar, of defining data, and of addressing complexity. The reversal we refer to is in the relationship between researcher and researched. If someone from another culture, especially a culture that might be the subject of U.S. ethnographic research, studies social life in the United States, we Americans become the objectified, the other. Ethnographic papers written by people who are unfamiliar with the institutions, customs, and practices of the United States reverse the relationship in which the U.S. ethnographer goes to "an-other" culture.

We want to introduce some examples from such papers, derived from projects carried out in the graduate fieldwork course taught by Stoeltje at the Folklore Institute at Indiana University. In this class, all of the students are required to visit a religious service unfamiliar to them and to write a paper on the experience which includes their emotional responses. U.S. students are often quite surprised at the strangeness of the experience and at their own responses. The international students find the experience challenging because they, like Westerners living in a foreign culture, are unfamiliar with the context of U.S. life as well as the particular religious service they attend. In many cases these students expect to return to their 
home countries, conduct fieldwork with villagers, and teach in the universities there, so they have not studied U.S. culture. A few comments from these brief ethnographic accounts afford us the opportunity not only to be objectified as the other but to realize the difficulties of dealing with complex societies and the range of individuals and groups that may interact with the researcher, wherever he or she may be.

One international student, Arzu Ôztûrkmen, begins her introduction by explaining her own religious background and how that shaped her expectations: "My knowledge about Christianity being mostly formed by an 'officially imposed' history about Crusades and various observations, I think that my image of Christianity is highly affected by the European tradition." We see then how she brings images of Christianity as practiced in Europe to the United States, creating expectations that do not apply and causing disjunction and confusion in her mind, not unlike the experience of U.S. students who make preparations for experience in another culture which prove to be inadequate, incorrect, or inapplicable, creating a disjunction between the knowledge gained from education and that obtained from observation. The student in this case observed ritual behaviors that reminded her of similar gestures from a totally different religious context, making it difficult to comprehend their meaning in this one:

Each time that the name of Christ was mentioned, people were raising their hands as a kind of salute. This instantly reminded me the "sala" of Moslems (at least Turkish Moslems) who usually put their right hand on their heart and salute Mohammed, their prophet, as his name is mentioned. . . My problem was rather a sense of estrangement. I was not feeling myself in a religious atmosphere, since my previous image about Christianity did not work there. I was able to clap and would probably be able to kneel down, but this "raising of hand" was a quite strong pattern for me, reminding me of propaganda or a "heil" salute.

The presentation of "entertainment" forms in the religious service presented her with a challenge also: "The most striking aspect of the Pentecostal Service is, in my opinion, its social aspect, by the fact that it organizes such a 'casino' that with all these show-men, band, puppets and so on, it gathers, entertains, relaxes all its audience, attaches them to its body and even rewards them."

In these insightful comments, the author explains that the college education she received in her own country did not prepare her for this kind of Christian practice, which left her with the impression of a casino or a show. Moreover, she faces the problem of placing this particular religious service within the larger context of U.S. Christianity. Were she in this country to conduct an ethnographic study of religion, it is possible she might return to her own university and write a dissertation on U.S. Christianity using this example to represent all Americans, a form of generalization all too often practiced by Americans working in other countries. ${ }^{16}$

In another instance, an individual from an African country attended an Episcopal service and reported an encounter with a hospitable member of the church. The friendly woman welcomed him, asked him if he were from Africa, and, when he answered "yes," assured him that she liked African Christians. While he appreciated 
her kindness, he felt hurt nevertheless that she assumed he was a Christian when he is, in fact, a Muslim. Although he did encounter a welcome, it would be quite easy for a person in his position to conclude that Americans are ignorant of the fact that Africans can be Muslims or perhaps to surmise that U.S. Christians only approve of African Christians and that if he had told her that he was Muslim, she might have assumed a different attitude. In any case, the discomfort he experienced because of the mistaken assumption could color his future observations and experiences.

Both of these individuals, one from Turkey and one from Somalia, experienced U.S. Christianity from a Muslim perspective, and in both cases the individuals encountered the unexpected. The two religious services and the membership of the churches were radically different from each other, demonstrating that even in the same town the category "Christianity" differs dramatically, making it impossible to generalize about the religion as a whole and making it difficult to understand how these versions of Christianity, particularly the Pentecostal one, relate to the cathedral Christianity of Europe. In their individual experiences, one encountered a gracious, hospitable, but perhaps patronizing individual who made incorrect assumptions about the visitor, and the other found herself very uncomfortable with some of the ritual acts in the service that brought to mind similar acts with totally different meanings. With very little effort, then, we could imagine some of the possible analyses and generalizations that a researcher from another culture, country, and religion might construct if conducting research on "religion in the United States" if that individual utilized some of the same stereotypes and ethnocentric views that Western ethnographers have all too often employed when studying other cultures.

\section{The Self as a Methodological Concern}

A convergence of the related forces discussed above has contributed to a new consciousness of the role of the individual self in ethnographic studies. Today's fieldworkers confront situations very different from those of previous generations who could obtain funds and go directly to "the people" they wished to study, encountering few of the financial and political hurdles that present themselves today. No longer is it possible to assume that an ethnographer can walk into other people's lives as if they represented "a field" and work that "field," ploughing and harvesting the data in a process known as "fieldwork." That position perpetuates the assumptions of Western superiority that have long burdened the ethnographic enterprise and exhibits an oblivion to the current globalization of experience and to the changing relations of power among world cultures. Yet to abandon the study of human culture at the very moment when social distances have decreased and the ability to communicate across boundaries has become not only possible but essential for survival would represent a failure to distinguish between structures of power that define research and the pursuit of knowledge that enlarges understanding. As fundamental shifts occur in every domain of human life, the need to advance our knowledge of social processes, local economies, unofficial authorities, 
human emotions, and artistic communication becomes urgent, insisting that we release ourselves from those remaining intellectual shackles of the 17th and 18th centuries and concentrate on new methodologies that take into account variables introduced by the self of the researcher: gender, ethnicity, age, class, marital status, purpose of research, and others.

Exploring the terrain for ethnographers in a world of postlocalities, Arjun Appadurai identifies the problem of intimacy as one of the interpretive challenges posed by globalization, namely, "how intimacy is produced and reproduced under the conditions of globalization" (1997:115). He articulates the challenge to ethnographers as a question of whether or not ethnography can retain "its special authority to report on the practices of intimacy in social life" (1997:116). In spite of the fact that the practices of intimacy are no longer contained in localities, communities, cultures, or societies, he believes that the routine work of social reproduction still involves "the mysteries of intimacy as an everyday social practice" (1997:116).

The following articles in this issue afford the opportunity to explore the experiences of two female folklore ethnographers engaged in the study of social reproduction in Mexico and the United States. Reflecting globalization in their own identities as well as in their research, each of them brings both an insider and an outsider perspective to her research. Both scholars completed their Ph.D.s in the United States. Nájera-Ramírez's first language is Spanish, and she returned to her mother's home country, Mexico, for her research. Epstein is a native of Israel, and while she has completed a wide range of ethnographic work there, her $\mathrm{Ph} . \mathrm{D}$. research was conducted in the United States with Bobover Hasidim. Each of them writes about the mysteries of intimacy as reflected in their fieldwork experiences. We are aware of gender in each case and of the effects of being a female researcher on the process of establishing oneself in the community and the influences it has on one's choices. We are also aware of the subjectivities each individual brings to the experience. The ambiguity of the terms insider and outsider is quite apparent, for each author might be considered an insider by some measures and an outsider by others. Each of the authors reveals to us not only the process by which she chose her subject and site but the challenges and opportunities she encountered along with the strategies she utilized in order to achieve her goals.

The two ethnographers demonstrate how they use their own identity, language, familiarity with religion, knowledge of family customs, and kin relationships to pursue their research agendas in depth. The importance of the ability to create and utilize relationships is particularly visible in these essays. In one instance the ethnographer creates something similar to fictive kin relationships by explaining her research agenda and eliciting cooperation and assistance from a religious authority; whereas in another, close relationships are created by living with a family, eliciting all the difficulties as well as advantages of a family household.

The authors present the complications of their fieldwork as it involved challenges to the self and struggle to negotiate their way through the maze of complications we all encounter in the mysteries of intimacy that constitute fieldwork. While some of these situations will be familiar, others will be totally strange, but 
we believe that they offer the opportunity for discussion centered on the self in fieldwork and that it will advance our methodologies to focus on the role of the particular fieldworker in a specific setting. There can hardly be any doubt that the research of a "native" person and that of an "outsider" will be different in many ways. This is not to argue that one is superior to the other but, rather, that we should explore the concept of "insider/outsider" to consider the implications and ambiguities of each individual's position. An understanding of the particular ethnographer's identity permits a further exploration of the strategies and goals that are most consistent with a particular ethnographic project (see Briggs 1986).

However, every insider as well as outsider should remind themselves frequently that the process of conducting research defines one as an outsider, whatever one's identity might be. Asking questions and making inquiries, taking notes and recording interviews may be received with enthusiasm in some locations, but more likely it will be regarded with suspicion. This means that those who succeed in telling us something valuable about a particular society or ethnographic subject are those who can negotiate relationships, and this generally means being aware of the self as well as the subject. It is, then, in the ambiguous space of the insider/outsider that all ethnographers must negotiate the distance generated when he or she begins research in a familiar culture and takes on the identity of an outsider or, to the contrary, when the outsider arrives as a stranger in a community and must negotiate an identity as an insider.

We want to emphasize, however, that perhaps no other identity feature is more significant than gender. Local gender practices remain in effect no matter who the visitor is. If one qualifies on some grounds as local, then one is assuredly expected to know and conform to those standards if one hopes to understand the mysteries of intimacy involved in social reproduction. But there are many degrees of variation in regard to gender, and an outsider, or a native person who has gone away for a graduate degree, must learn to take into account the local attitudes about outsiders, as well, and what advantages or disadvantages may lie in defining oneself as an outsider and, alternatively, which ones lie in building the concept of insider. From here, the researcher must determine which strategies to utilize that will affect decisions concerning where to live, how to dress, eating habits, and other everyday practices. ${ }^{17}$

Perhaps because female ethnographers have encountered many obstacles based on gender concepts, it may be no surprise that the two authors of the following essays are female. Or perhaps women are concerned with the self in fieldwork because women are associated with domestic, intimate spaces in many cultures and the negotiation of self is an intimate process. In any case, we have the evidence in published accounts, from Hurston and Parsons to the present authors, that women have written reflexively about social reproduction. Certainly in recent decades the publications on fieldwork have burgeoned, produced by both women and men, but those that focus on the way in which the fieldworker's identity influenced the research project are more often written by women. Consequently, these new vantage points and the detailed information on the methods and obstacles encountered in fieldwork are bringing to light new perspectives and constituting 
a source of new theories as well as methods, equally as relevant to male ethnographers as to female ones. For these reasons we believe this group of essays has value for the incoming generations of ethnographers as well as for researchers who continue to be interested in fieldwork, whether it be "domestic" or "foreign," folklore or anthropology, "applied" or "academic."

In a conceptual move away from "objectivity," and in response to policies set by those who constitute the subject of research, ethnographers have begun to develop their own consciousness and evaluate their cultural practices, especially the assumptions on which their research rests and the way these affect their rapport with and integration into the host community. The significance of the self has relevance for all dimensions of this research, encompassing the mundane as well as the sublime, the cultural as well as the personal. Pat Caplan describes this relevance as the hermeneutic circle and defines it as follows: "we are all intimately (personally, socially and historically) involved with what we claim to know" (1994:70). Individuals engaged in ethnographic research benefit most from looking into the pool when the self has been integrated into the research model, recognizing its complexity and its attached cultural practices, for it is the self that enters into negotiations, or does not, with the people one wishes to study, and it is the self that ultimately accounts for the data, the representations, and the theoretical interpretation of the ethnographic work.

\section{Notes}

Stoeltje acknowledges with gratitude her year as a Weatherhead Scholar at the School of American Research, where she was able to complete this article.

${ }^{1}$ George Marcus, James Clifford, and Michael Fischer have written at length on this subject from an anthropological perspective (Clifford 1988; Marcus and Clifford 1986; Marcus and Fischer 1986). See also Olson and Hirsch 1995.

${ }^{2}$ An excellent collection of studies in which the authors share experiences in the field that were affected or determined by matters of identity and the self is Self, Sex and Gender in Cross-Cultural Fieldwork (Whitehead and Conaway 1986). See also Bamford 1997.

${ }^{3}$ See Judith Okely's Own or Other Culture (1996) for articles by anthropologists on fieldwork in the "West" which discuss questions of reflexivity and autobiography in fieldwork.

${ }^{4}$ The phrase "people studying people" is taken from Robert A. Georges and Michael Owen Jones's book on fieldwork by that title (1980).

${ }^{5}$ See Diane Wolfs Feminist Dilemmas in Fieldwork (1996) for a rich collection of essays that describe fieldwork experiences, revealing the ethnographer's assumptions, expectations, and obstacles encountered. In almost every article, the author highlights experiences that reveal the significance of the self in fieldwork circumstances, stimulating the reader to contemplate the range of limitations, strategies, and opportunities present in each setting.

${ }^{6}$ For more on Parsons, see her 1937 review of Zuni Mythology by Ruth Benedict (1935) and Zuni Texts by Ruth Bunzel (1933).

${ }^{7}$ Hurston's best-known folklore work is Mules and Men (1990, originally published in 1935). She incorporated much of the material from that work into her novel Their Eyes Were Watching God (1937), a work that is now much discussed by literary scholars. For a selection from her nonfiction essays and excerpts from both of the previously mentioned works, see I Love Myself When I Am Laughing . . . and Then Again When I Am Looking Mean and Impressive (1979). 
${ }^{8}$ Dorson added an insightful note that falls outside of his historical model and the collection-oftexts model to the effect that jokes and anecdotes circulating in oral tradition "plumb deeply into the troubled currents of our culture" (1959:209).

${ }^{9}$ About the folksong specialists Dorson says, "A bystander [at the American Folklore Society meetings] gains the impression that America is a land of troubadours whose inhabitants carol before breakfast, woo at luncheon with love lyrics, entertain in the evening with ballad shockers, and retire with gospel hymns, folk of course" (1959:200).

${ }^{10} \mathrm{We}$ see a similar phenomenon taking place in anthropology today as the result of the critique of the field. George Marcus states this chronology as follows: "After a strong critical reflection in the 1980 s upon the historical project of cultural anthropology as a discipline, articulated through an assessment of its rhetorical traditions, we are now in the midst of a rethinking of the ideology of its distinctive method of fieldwork" (1997:104).

${ }^{11}$ See Dorson's introduction to Buying the Wind (1964), in which he discusses his views on fieldwork as they were shaped by his own collection trips in Michigan, Maine, and African American communities in the South. Donald MacDonald's essay "Fieldwork: Collecting Oral Literature" in Folklore and Folklife offers another such traditional approach-for example, "Admittedly almost anyone can go into a tradition-rich area and pick up something useful, but systematic fieldwork usually begins at the desk" (1972:407) - and recounts several of Dorson's own suggestions.

${ }^{12}$ Several of these stories appeared in Richard Bauman's (1986) study of four male narrators in Texas, Story, Performance, and Event: Contextual Studies of Oral Narrative. The stories are published under the pseudonym Caswell Rogers.

${ }^{13}$ An updated listing of Indiana University folklore dissertations is now available, courtesy of Christie L. Fox and Stephen Olbrys. This idea was influenced by the bibliography of dissertations published by Alan Dundes in 1976.

${ }^{14}$ The dissertation was later published as The Art of the Festival (Smith 1975).

${ }^{15}$ Georges and Jones (1980) significantly added to this discussion.

${ }^{16} \mathrm{We}$ are indebted to Arzu Ôztûrkmen of Bagazici University in Istanbul for permission to quote from her paper.

${ }^{17}$ For more on foodways and eating, see Abrahams 1984.

\section{References Cited}

$\rightarrow$ Abrahams, Roger D. 1971. Personal Power and Social Restraint in the Definition of Folklore. Journal of American Folklore 84:16-30.

1984. Equal Opportunity Eating. In Ethnic and Regional Foodways in the United States: The Performance of Group Identity, ed. Linda Keller Brown and Kay Mussell, pp. 19-36. Knoxville: University of Tennessee Press.

Abu-Lughod, Lila. 1990. Can There Be a Feminist Ethnography? Women and Performance 5(1):7-27.

Adams, Robert J. 1972. Social Identity of a Japanese Storyteller. Ph.D. dissertation, Folklore Department, Indiana University.

Appadurai, Arjun. 1997. Fieldwork in the Era of Globalization. Anthropology and Humanism 22:115-118.

Babcock, Barbara, ed. 1991. Pueblo Mothers and Children: Essays by Elsie Clews Parsons 1915-1924. Santa Fe, N.Mex.: Ancient City Press.

Bamford, Sandra. 1997. Beyond the Global: Intimacy and Distance in Contemporary Fieldwork. $A n$ thropology and Humanism 22:110-114.

Bauman, Richard. 1986. Story, Performance, and Event: Contextual Studies of Oral Narrative. New York: Cambridge University Press.

Bauman, Richard, and Roger Abrahams, eds. 1981. "And Other Neighborly Names": Social Process and Cultural Image in Texas Folklore. Austin: University of Texas Press.

Benedict, Ruth. 1935. Zuni Mythology. New York: Columbia University Press.

Briggs, Charles. 1986. Learning How to Ask: A Sociolinguistic Appraisal of the Role of the Interview in Social Science Research. New York: Cambridge University Press. 
Bunzel, Ruth. 1933. Zuni Texts. New York: G. E. Stechert.

Caplan, Pat. 1994. Engendering Knowledge: The Politics of Ethnography. In Persons and Powers of

Women in Diverse Cultures, ed. Shirley Ardener, pp. 65-87. New York: Berg.

Clifford, James. 1988. The Predicament of Culture. Cambridge, Mass.: Harvard University Press.

$\rightarrow$ Dorson, Richard M. 1959. A Theory for American Folklore. Journal of American Folklore 72:197-215. 1964. Buying the Wind. Chicago: University of Chicago Press. ed. 1972a. African Folklore. Bloomington: Indiana University Press. ed. 1972b. Folklore and Folklife. Chicago: University of Chicago Press. ed. 1983. Handbook of American Folklore. Bloomington: Indiana University Press.

Dundes, Alan. 1976. Folklore Theses and Dissertations in the United States. Austin: University of Texas Press.

Farrer, Claire. 1975. Women and Folklore. Austin: University of Texas Press. (Original "Women and Folklore," special issue of Journal of American Folklore 88[347], 1975.)

Finnegan, Ruth. 1992. Oral Traditions and the Verbal Arts: A Guide to Research Practices. New York: Routledge.

Floyd, Robbie Davis. 1986. Birth as an American Rite of Passage. Ph.D. dissertation, Anthropology Department, University of Texas at Austin.

$\rightarrow$ Gayton, Awna H. 1942. English Ballads and Indian Myths. Journal of American Folklore 55:121-125.

Georges, Robert A., and Michael Owen Jones. 1980. People Studying People: The Human Element in Fieldwork. Berkeley: University of California Press.

Golde, Peggy, ed. 1970. Women and the Field: Anthropological Experiences. Chicago: Aldine.

$\rightarrow$ Haun, Eugene. 1959. Lares and Penates, Once Removed. Journal of American Folklore 71:243-247.

Hollis, Susan Tower, Linda Pershing, and M. Jane Young, eds. 1993. Feminist Theory and the Study of Folklore. Urbana: University of Illinois Press.

Hurston, Zora Neale. 1937. Their Eyes Were Watching God. Philadelphia: J. B. Lippincott Co. 1979. I Love Myself When I Am Laughing . . . and Then Again When I Am Looking Mean and Impressive. Ed. Alice Walker. Old Westbury, N.Y.: Feminist Press. 1990[1935]. Mules and Men. New York: Harper Perennial Press.

Ice, Joyce. 1984. Quilting and the Pattern of Relationships in Community Life. Ph.D. dissertation, Anthropology Department, University of Texas at Austin.

Jordan, Rosan. 1975. The Folklore and Ethnic Identity of a Mexican-American Woman. Ph.D. dissertation, Folklore Department, Indiana University.

Jordan, Rosan, and Susan Kalĉik, eds. 1985. Women's Folklore, Women's Culture. Philadelphia: University of Pennsylvania Press.

Lambek, Michael. 1997. Pinching the Crocodile's Tongue: Affinity and the Anxieties of Influence in Fieldwork. Anthropology and Humanism 22:31-53.

Lee, Dorothy S. 1984. Music Performances and the Negotiation of Identity in Eastern Viti Levu, Fiji. Ph.D. dissertation, Folklore Department, Indiana University.

Lévi-Strauss, Claude. 1955. Tristes Tropiques. Paris: Plon. 1969. The Raw and the Cooked. New York: Harper and Row.

MacDonald, Donald. 1972. Fieldwork: Collecting Oral Literature. In Folklore and Folklife, ed. Richard M. Dorson, pp. 407-430. Chicago: University of Chicago Press.

Marcus, George E., ed. 1992. Rereading Cultural Anthropology. Durham, N.C.: Duke University Press. 1997. The Uses of Complicity in the Changing Mise-en-Scène of Anthropological

Fieldwork. Representations 59:85-108.

Marcus, George E., and James Clifford, eds. 1986. Writing Culture: The Poetics and Politics of Ethnography, a School of American Research Advanced Seminar. Berkeley: University of California Press.

Marcus, George E., and Michael J. J. Fischer. 1986. Anthropology as Cultural Critique. Chicago: University of Chicago Press.

Miller, Edward K. 1981. An Ethnography of Singing: The Use and Meaning of Song in Three Generations of a Scottish Family. Ph.D. dissertation, Anthropology Department, University of Texas at Austin.

Nájera-Ramírez, Olga. 1997. La Fiesta de Los Tastoanes: Critical Encounters in Mexican Festival Performance. Albuquerque: University of New Mexico Press. 
Okely, Judith. 1996. Own or Other Culture. New York: Routledge.

Olson, Gary A., and Elizabeth Hirsch, eds. 1995. Women Writing Culture. Albany: State University of New York Press.

Paredes, Américo. 1993. On Ethnographic Work among Minority Groups: A Folklorist's Perspective. In Folklore and Culture on the Texas-Mexican Border, ed. Richard Bauman, pp. 73-110. Austin: Center for Mexican American Studies at University of Texas. (Original “On Ethnographic Work among Minority Groups: A Folklorist's Perspective,” New Scholar 6:1-32,1977.)

Paredes, Américo, and Richard Bauman, eds. 1972. Toward New Perspectives in Folklore. Austin: University of Texas Press.

$\rightarrow$ Parsons, Elsie Clews. 1937. Review of Zuni Mythology and Zuni Texts. Journal of American Folklore 50:107-109.

Pavlic, Edward. 1997. Crossroads and Consciousness: Communal Underground Space and Diasporic Modernism in African-American Literature. Ph.D. dissertation, Folklore Department, Indiana University.

Singer, Roberta L. 1982. My Music Is Who I Am and What I Do: Latin Popular Music and Identity in New York City. Ph.D. dissertation, Folklore Department, Indiana University.

Smith, Robert J. 1969. A Peruvian Patronal Fiesta: Its Components and Their Interrelations. Ph.D. dissertation, Anthropology Department, Indiana University. 1975. The Art of the Festival. Lawrence: University of Kansas Press.

Stahl, Sandra K. D. 1975. The Personal Narrative as a Folklore Genre. Ph.D. dissertation, Folklore Department, Indiana University.

Stoeltje, Beverly J. 1975. Helpmate for Man Indeed. In Women and Folklore, ed. Claire Farrer, pp. 25-41. Austin: University of Texas Press.

Weigle, Marta. 1982. Spiders and Spinsters: Women and Mythology. Albuquerque: University of New Mexico Press.

White, Marilyn. 1983. "We Lived on an Island": An Afro-American Family and Community in Rural Virginia, 1865-1940. Ph.D. dissertation, Anthropology Department, University of Texas at Austin.

Whitehead, Tony Larry, and Mary Ellen Conaway. 1986. Self, Sex and Gender in Cross-Cultural Fieldwork. Urbana: University of Illinois Press.

Wolf, Diane L., ed. 1996. Feminist Dilemmas in Fieldwork. Boulder, Colo.: Westview Press.

Yocom, Margaret R. 1980. Fieldwork in Family and Oral History: A Study in Methodology. Ph.D. dissertation, English Department, University of Massachusetts. 